\title{
Aerobic digestion reduces the quantity of antibiotic resistance genes in residual municipal wastewater solids
}

\author{
Tucker R. Burch ${ }^{1}$, Michael J. Sadowsky ${ }^{2}$ and Timothy M. LaPara ${ }^{1,2 *}$ \\ Department of Civil Engineering, University of Minnesota, Minneapolis, MN, USA \\ 2 Biotechnology Institute, University of Minnesota, St. Paul, MN, USA
}

\author{
Edited by: \\ Marilyn C. Roberts, University of \\ Washington, USA \\ Reviewed by: \\ M. Pilar Francino, Center for Public \\ Health Research, Spain \\ Peter Pristas, Slovak Academy of \\ Sciences, Slovakia \\ *Correspondence: \\ Timothy M. LaPara, Department of \\ Civil Engineering, University of \\ Minnesota, 500 Pillsbury Drive SE \\ Minneapolis, MN 55455, USA. \\ e-mail: lapar001@umn.edu
}

Numerous initiatives have been undertaken to circumvent the problem of antibiotic resistance, including the development of new antibiotics, the use of narrow spectrum antibiotics, and the reduction of inappropriate antibiotic use. We propose an alternative but complimentary approach to reduce antibiotic resistant bacteria (ARB) by implementing more stringent technologies for treating municipal wastewater, which is known to contain large quantities of ARB and antibiotic resistance genes (ARGs). In this study, we investigated the ability of conventional aerobic digestion to reduce the quantity of ARGs in untreated wastewater solids. A bench-scale aerobic digester was fed untreated wastewater solids collected from a full-scale municipal wastewater treatment facility. The reactor was operated under semi-continuous flow conditions for more than 200 days at a residence time of approximately 40 days. During this time, the quantities of tet(A), tet $(\mathrm{W})$, and erm(B) decreased by more than $90 \%$. In contrast, int/1 did not decrease, and tet $(\mathrm{X})$ increased in quantity by 5 -fold. Following operation in semi-continuous flow mode, the aerobic digester was converted to batch mode to determine the first-order decay coefficients, with half-lives ranging from as short as 2.8 days for tet $(\mathrm{W})$ to as long as 6.3 days for int/1. These results demonstrated that aerobic digestion can be used to reduce the quantity of ARGs in untreated wastewater solids, but that rates can vary substantially depending on the reactor design (i.e., batch vs. continuous-flow) and the specific ARG.

Keywords: antibiotic resistance genes, municipal wastewater treatment, aerobic digestion, class 1 integrons, qPCR

\section{INTRODUCTION}

The resistance of pathogenic bacteria to antibiotic chemotherapy is a growing problem with significant consequences for public health. In the United States, methicillin-resistant Staphylococcus aureus (MRSA) infections lead to more fatalities than the combination of HIV/AIDs, Parkinson's disease, and homicides (Spellberg et al., 2011). The estimated economic cost of antibiotic resistance ranges from $\$ 21$ to 34 billion dollars per year (Spellberg et al., 2011). In response, medical practitioners have attempted to reduce the number of inappropriate and unnecessary antibiotic prescriptions. The biomedical research community is also focusing its research efforts to develop new antibiotics as well as alternatives to antibiotic chemotherapy (Kohanski et al., 2010; Jabes, 2011; Edgar et al., 2012). Finally, in Sweden and Switzerland, the use of antibiotics in agriculture for growth promotion and prophylaxis has been banned (Wierup, 2001; Arnold et al., 2004).

Despite these initiatives, a significant body of research suggests that antibiotic resistant bacteria (ARB) are becoming increasingly more prevalent (Palumbi, 2001; Levy and Marshall, 2004; Levy, 2005). An alternative, but complementary, approach to reducing the prevalence of ARB would be to identify pertinent reservoirs of resistance and then to implement appropriate technologies to ameliorate these reservoirs. Consistent with this approach, numerous studies have identified untreated municipal wastewater (raw sewage) as a significant reservoir of ARB and antibiotic resistance genes (ARGs) (Bönemann et al., 2006; da Silva et al., 2006; Auerbach et al., 2007; Schlüter et al., 2007; Szczepanowski et al., 2009; Zhang et al., 2009a; Galvin et al., 2010; Uyaguari et al., 2011; Zhang and Zhang, 2011). Municipal wastewater treatment processes, therefore, should represent an important opportunity to mitigate the quantity of this reservoir of antibiotic resistance.

Although prior research has demonstrated that the treated municipal wastewater also contains substantial concentrations of ARB and ARGs (da Silva et al., 2006; Pruden et al., 2006; Graham et al., 2011; LaPara et al., 2011), a mass balance on wastewater treatment operations suggests that $>99 \%$ of the ARB and ARGs in untreated municipal wastewater accumulate in the residual wastewater solids. These are subsequently treated by numerous technologies to reduce their nutrient and pathogen content (to varying degrees) prior to their disposal on agricultural land (Tchobanoglous et al., 2003). There have been relatively few investigations on the different technologies used for treating residual wastewater solids and their associated effectiveness at mitigating ARB and ARGs. Diehl and LaPara (2010) observed relatively little removal of ARGs in aerobic digestion processes operated at $22-55^{\circ} \mathrm{C}$, but observed increasingly effective removal of ARGs in anaerobic digestion processes at temperature $>37^{\circ} \mathrm{C}$. In contrast, Ma et al. (2011) observed little benefit of increasing the temperature of anaerobic digestion beyond $37^{\circ} \mathrm{C}$. 
In the present research, we undertook a detailed investigation of the effectiveness of a bench-scale conventional aerobic digestion process at mitigating the quantity of ARGs in untreated residual wastewater solids. Although our prior research had observed no effect of aerobic digestion on the quantity of ARGs in wastewater solids (Diehl and LaPara, 2010), these previous experiments were performed in relatively small bioreactors with a mean hydraulic residence time of 4 days. Assuming that ARGs decay at a relatively slow rate (i.e., half-lives $>4$ days), this experimental design would have been insufficient to observe significant reductions in ARGs. This short time period used in our prior experimental design is also pertinent because the United States Environmental Protection Agency requires that aerobic digestion processes have a mean hydraulic residence time of 40 days (when operated at $20^{\circ} \mathrm{C}$ ) to qualify as a "process to significantly reduce pathogens" (PSRP), which must be achieved before these treated wastewater solids can be applied to agricultural land for their disposal (albeit with some restrictions) (Tchobanoglous et al., 2003). This research is of considerable practical importance because numerous full-scale municipal wastewater treatment facilities currently utilize aerobic digestion processes to treat their wastewater solids, particularly those that treat less than 10 million gallons of wastewater each day (at higher flow rates, other technologies are considered more practical and economical).

\section{MATERIALS AND METHODS EXPERIMENTAL DESIGN}

A 10-L aerobic digester was operated at room temperature with a mean residence time of 40 days and a minimum dissolved oxygen (DO) concentration of $2 \mathrm{mg} / \mathrm{L}$. The digester was inoculated with $10 \mathrm{~L}$ of untreated residual municipal wastewater solids from a full-scale municipal wastewater treatment plant. Mixing and aeration were provided by pumping atmospheric air through a stone diffuser located at the bottom of the reactor vessel at a rate sufficient to prevent settling of solids and to maintain the minimum DO concentration. Typical operating variables, including temperature, $\mathrm{DO}, \mathrm{pH}$, total solids, volatile solids, and inert solids, were monitored throughout the entire time period the digester was in operation (Clesceri et al., 1999). The total solids concentration represents the quantity of material remaining after drying at $103^{\circ} \mathrm{C}$ (i.e., the sum of inorganic and organic material dissolved and suspended in the sample). In contrast, the volatile solids concentration represents the fraction of the total solids concentration that is lost upon ignition at $550^{\circ} \mathrm{C}$, whereas the IS concentration represents the fraction of the total solids that is not lost upon ignition at $550^{\circ} \mathrm{C}$ (i.e., the fraction of the total solids that represents that ash-material). Water loss from the digestor due to evaporation was monitored and replaced by adding appropriate volumes of deionized water to the digester.

The digester was operated for more than 175 days while being fed on a weekly basis untreated residual municipal wastewater solids. The digester was considered to have reached steady-state conditions once the residence time for inert solids (i.e., the average amount of time that an "inert solid" would reside in the aerobic digester) had been maintained at $41.1 \pm 0.5$ days (mean \pm standard deviation) for a time period of 35 days. Once steady-state conditions had been established, the operating mode of the digester was shifted to better reflect continuous-flow operating conditions by feeding untreated residual municipal wastewater solids on a daily basis from Day 180 to Day 191. Following this semi-continuous flow phase, the aerobic digester was operated for an additional 27 days while being fed on a weekly basis untreated residual municipal wastewater solids. On Day 218, half of the digester contents (i.e., $5 \mathrm{~L}$ ) were replaced with untreated residual municipal wastewater solids to allow the determination of decay coefficients in a batch-like reactor.

\section{SAMPLE COLLECTION AND GENOMIC DNA EXTRACTION AND PURIFICATION}

Triplicate samples $(100 \mu \mathrm{L})$ were collected from larger aliquots $(50-300 \mathrm{~mL})$ of digester contents to ensure accurate sample collection volumes. Samples were then diluted with $500 \mu \mathrm{L}$ of lysis buffer (120 mM sodium phosphate buffer, 5\% dodecyl sulfate, $\mathrm{pH}$ $8.0 \pm 0.1)$ and subjected to three consecutive freeze-thaw cycles followed by incubation at $70^{\circ} \mathrm{C}$ for $90 \mathrm{~min}$. Genomic DNA was then extracted using a FastDNA Spin Kit (MP Biomedicals LLC, Solon, $\mathrm{OH}$ ) according to the manufacturer's instructions.

\section{REAL-TIME PCR}

Real-time PCR was used to quantify the concentrations of three different genes that encode resistance to tetracycline [tet $(\mathrm{A})$, tet $(\mathrm{W})$, and tet $(\mathrm{X})]$, one gene that encodes resistance to erythromycin $[\operatorname{erm}(\mathrm{B})]$, one gene that encodes resistance to sulfonamides (sul1), and the integrase gene of class 1 integrons (intI1). The three tetracycline resistance genes were selected because they represent each of the three known mechanisms of tetracycline resistance (efflux pumps, ribosomal protection proteins, and enzymatic modification) (Levy et al., 1999). The erythromycin gene, $\operatorname{erm}(\mathrm{B})$, was chosen because it encodes an rRNA methyltransferase that confers resistance to macrolides, lincosamides, and streptogramin B (Roberts et al., 1999). Prior work has demonstrated that all five of these ARGs are present at substantial concentrations in wastewater and/or wastewater solids (Diehl and LaPara, 2010; LaPara et al., 2011; Munir et al., 2011). Class 1 integrons were quantified because of their association with multiple antibiotic resistance. These integrons enable bacteria to collect multiple, exogenous ARGs and modulate their expression (Mazel, 2006). qPCR was also used to determine the concentrations of 16S rRNA genes (a measure of total bacterial biomass), all Bacteroides spp. (a measure of total fecal bacteria), and human-specific Bacteroides spp. (a measure of human fecal bacteria) (Muyzer et al., 1993; Bernhard and Field, 2000; Layton et al., 2006). Additional information regarding the use of qPCR to quantify these genes can be found in Table $\mathbf{1}$.

Real-time PCR was carried out on an Eppendorf Mastercycler EP Realplex thermal cycler (Eppendorf, Westbury, NY). PCR assays were optimized to reduce or eliminate the formation of primer-dimers and non-specific products. Typical PCR assays began with a $1 \mathrm{~min}$ initial denaturation at $95^{\circ} \mathrm{C}$. This step was followed by 40 cycles of denaturation at $95^{\circ} \mathrm{C}$ for $15 \mathrm{~s}$ and combined annealing and extension at the primer-specific annealing temperature for $1 \mathrm{~min}$. Typical reaction volumes were $25 \mu \mathrm{L}$ and consisted of $12.5 \mu \mathrm{L}$ of BioRad iTaq SYBR Green Supermix with ROX 
Table 1 | Gene targets, resistance mechanisms, primer sequences, amplicon sizes, and annealing temperatures for real-time PCR assays.

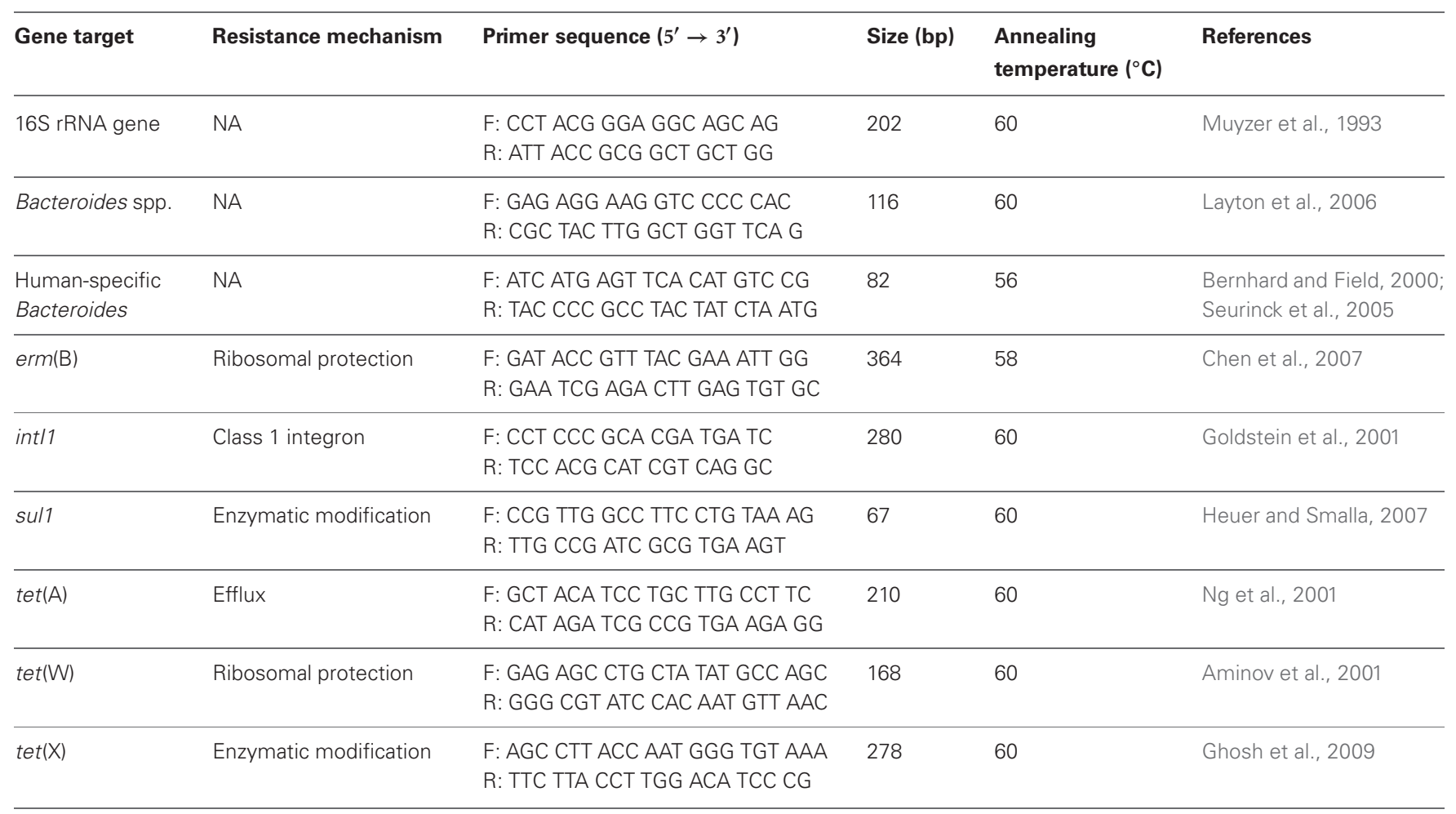

(Life Science Research, Hercules, CA), $25 \mu \mathrm{g}$ of bovine serum albumin, optimized quantities of forward and reverse primers, and approximately $1 \mathrm{ng}$ of template genomic DNA. Each analysis consisted of three replicates. Standards were made from PCR products that targeted specific genes from either well-described bacterial isolates or from municipal wastewater solids. PCR products were ligated into a pGEM-T Easy cloning vector, transformed into JM109 competent cells, and extracted from cell cultures using the alkaline lysis procedure (Sambrook et al., 1989). It was confirmed that all plasmids contained the specified gene by nucleotide sequence analysis of the extracted plasmid. The DNA concentration of plasmid extracts was quantified using a TD-700 fluorometer and Hoechst 33258 dye. Each standard curve consisted of a 10-fold dilution series containing at least 5 standards $\left(r^{2} \geq 0.99\right)$. Amplification efficiencies were $100 \pm 10 \%$.

\section{DATA ANALYSIS}

All data obtained from groups of triplicate samples were treated as if they had been obtained from a normal distribution (i.e., means and standard deviations were used to describe the data). This assumption of normal distributions was based on results from Shapiro-Wilk normality tests performed in SigmaPlot 12.0 that indicated the complete semi-continuous flow data series for most gene targets could not be distinguished from a normal distribution $(P>0.05)$. Analysis of variance (ANOVA; Microsoft Excel 2010) was used with data from the semi-continuous flow experiment to determine the statistical significance of differences in gene target concentrations between untreated and treated residual solids samples.
Simple linear regression (Arc 1.06) was used with logtransformed data from the batch experiment to determine the goodness of fit of the data to a first-order kinetic model. The first-order kinetic model was chosen based on previous empirical observations that it tends to fit this type of data well. Values of $P$ used to compare the relative statistical significance of different kinetic coefficients (Table 4) were determined using Welch's $t$-test for unequal $n$ and unequal sample variance. The sample variance for each estimated first-order kinetic coefficient was obtained from the estimated standard error for that coefficient as provided by Arc 1.06 .

\section{RESULTS}

\section{SEMI-CONTINUOUS FLOW OPERATING MODE}

With respect to typically monitored operating variables, the labscale aerobic digester performed as an appropriate experimental model simulation during the semi-continuous flow experimental period (Table 2). The $\mathrm{pH}$ was circumneutral, digester temperature was the same as the ambient air temperature, and DO concentrations were well above the target DO concentration of $2 \mathrm{mg} / \mathrm{L}$. The total and volatile solids concentrations for the untreated and treated solids were well within ranges typically encountered in practice (2-5\% total solids, $0.6-3 \%$ volatile solids) (Tchobanoglous et al., 2003). The fractions of total and volatile solids destroyed were 26 and $41 \%$, respectively, which is also typical for a full-scale aerobic digestion process (Tchobanoglous et al., 2003).

The aerobic digester eliminated a substantial fraction of bacterial biomass and fecal indicator bacteria (FIB) as measured by 
Table 2 | Operating variables during operation in semi-continuous flow mode.

\begin{tabular}{lcc}
\hline Variable & Mean \pm SD & $\boldsymbol{n}$ values \\
\hline $\mathrm{pH}$ & $7.5 \pm 0.2$ & $n=12$ \\
Temperature ( ${ }^{\circ} \mathrm{C}$ ) & $17.0 \pm 0.3$ & $n=12$ \\
Dissolved oxygen (mg/L) & $5.8 \pm 1.5$ & $n=12$ \\
Hydraulic residence time (days) & $13.5 \pm 0.7$ & $n=12$ \\
Untreated total solids & $4.6 \% \pm 0.04 \%$ & $n=4$ \\
Treated total solids & $3.4 \% \pm 0.3 \%$ & $n=4$ \\
Total solids destruction & $26.3 \% \pm 6.0 \%$ & $n=4$ \\
Total solids residence time (days) & $33.1 \pm 0.4$ & $n=12$ \\
Untreated volatile solids & $3.2 \% \pm 0.05 \%$ & $n=4$ \\
Treated volatile solids & $1.9 \% \pm 0.1 \%$ & $n=4$ \\
Volatile solids destruction & $41.1 \% \pm 4.8 \%$ & $n=4$ \\
Volatile solids residence time (days) & $27.7 \pm 0.6$ & $n=12$ \\
Untreated inert solids & $1.5 \% \pm 0.02 \%$ & $n=4$ \\
Treated inert solids & $1.5 \% \pm 0.1 \%$ & $n=4$ \\
Inert solids destruction & $-5.7 \% \pm 8.4 \%$ & $n=4$ \\
Inert solids residence time (days) & $41.7 \pm 0.1$ & $n=12$ \\
\hline
\end{tabular}

qPCR targeting the 16S rRNA gene and $16 \mathrm{~S}$ rRNA genes specific for all Bacteroides spp. and for human-specific Bacteroides spp. (Figure 1). The concentrations of 16S rRNA genes were $77 \%$ lower in treated samples compared to the untreated samples. This indicates net destruction of total bacterial biomass in the digester, consistent with the total and volatile solids removal. Significant removal was observed for both types of FIB. The concentrations of all Bacteroides spp. were $99.9 \%$ lower in treated samples compared to untreated samples. Similarly, the concentrations of human-specific Bacteroides spp. were approximately $5 \times 10^{8}$ gene copies $\mathrm{mL}^{-1}$ in untreated samples, but were below the detection limit $\left(1 \times 10^{8}\right.$ gene copies $\left.\mathrm{mL}^{-1}\right)$ in treated samples.

The untreated wastewater solids contained substantial quantities of each of the ARGs investigated in this study. The quantities of intI1, sul1, and tet(W) were similar, present at a concentration of approximately $10^{10}$ gene copies $\mathrm{mL}^{-1}$. In contrast, the concentration of $\operatorname{erm}(\mathrm{B})$ was approximately $10^{11}$ gene copies $\mathrm{mL}^{-1}$, and the concentrations of tet $(\mathrm{A})$ and $\operatorname{tet}(\mathrm{X})$ were approximately $10^{9}$ gene copies $\mathrm{mL}^{-1}$. Given that the concentrations of $16 \mathrm{~S}$ rRNA genes were approximately $10^{12}$ gene copies $\mathrm{mL}^{-1}$ in the untreated solids, the ratio of the various antibiotic resistance determinants examined in this study to bacterial cells ranged from approximately $0.1 \%$ for tet $(\mathrm{A})$ and $\operatorname{tet}(\mathrm{X})$ to $1 \%$ for intI1, sull, and tet $(\mathrm{W})$, and to $10 \%$ for erm (B).

The bench-scale aerobic digester removed between 85 and $98 \%$ of $\operatorname{erm}(\mathrm{B}), \operatorname{sull}$, tet(A), and tet(W) during the semi-continuous flow experimental period (Figure 2), which was substantially greater than that for bacterial biomass (i.e., 16S rRNA genes). In contrast, the quantity of intI1 was not statistically different $(P=0.17)$ in the untreated and treated solids, suggesting that aerobic digestion operated in semi-continuous flow mode does not eliminate intI1 (Figure 3). Furthermore, the ratio of intI1 to $16 \mathrm{~S}$ rRNA genes increased in the treatment process from 0.8 to $3 \%$, indicating that aerobic digestion likely selects for bacterial

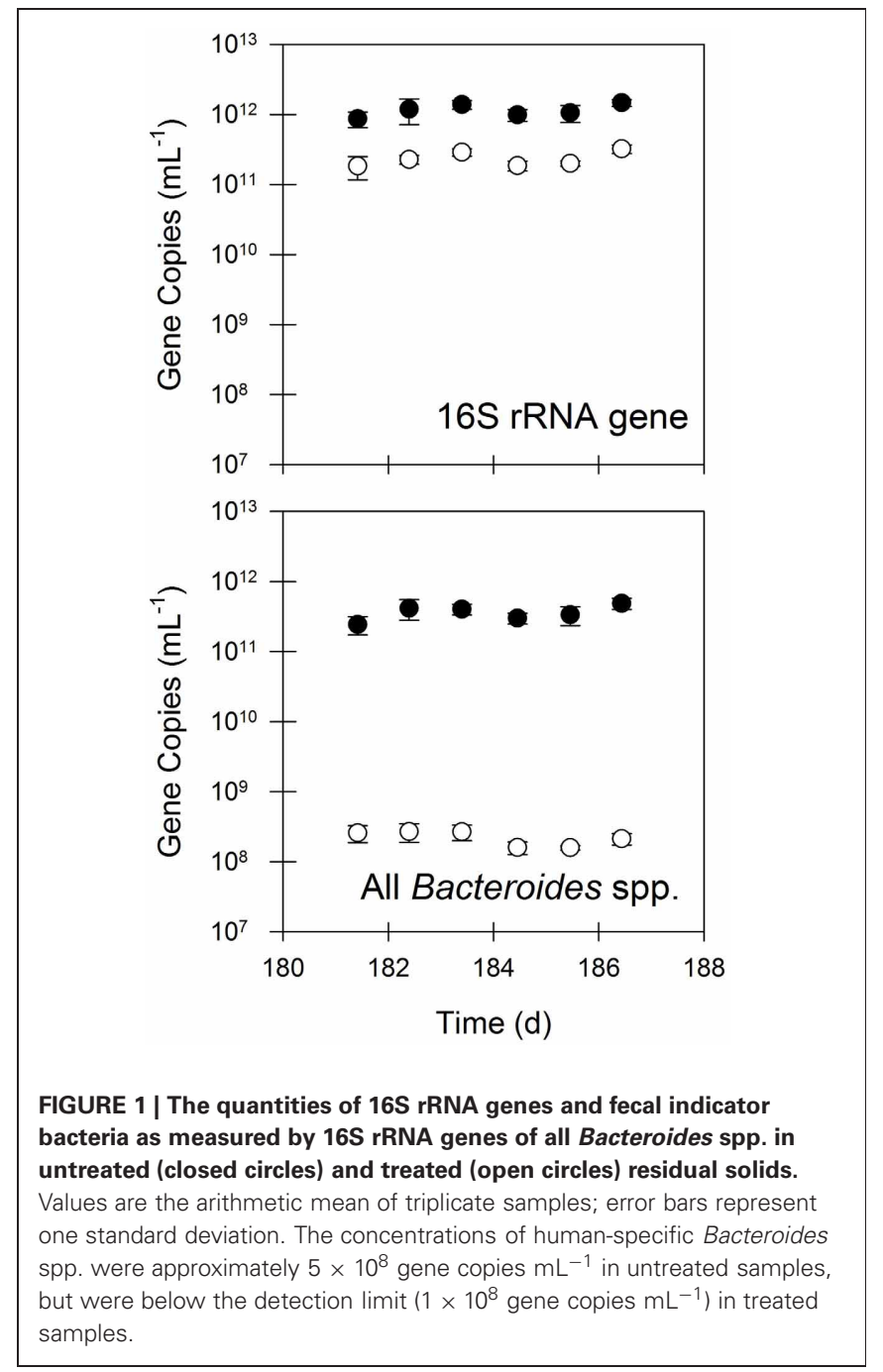

cells possessing a class 1 integron. Interestingly, the aerobic digestion process also appeared to select for bacterial cells containing tet $(\mathrm{X})$, as the quantity of this gene was 5 -fold greater in the treated solids than in the untreated solids.

\section{BATCH OPERATING MODE}

Following the semi-continuous flow experimental phase, the aerobic digester was shifted to batch mode to determine decay rates for each target gene. As with the previous experimental phase, typically monitored operating variables indicated that the digester operated as an appropriate simulation of a full-scale aerobic digester. The $\mathrm{pH}$ rose from a semi-continuous phase value between 7 and 7.5 to just above 8 following the addition of untreated residual solids, but then gradually decreased to between 7 and 7.5. A substantial decrease in DO concentration to less than $1 \mathrm{mg} / \mathrm{L}$ was initially observed, but increased to $>4 \mathrm{mg} / \mathrm{L}$ within $24 \mathrm{~h}$ and remained so for the duration of the batch experiment.

A significant decay rate was observed for $16 \mathrm{~S}$ rRNA genes and FIB during operation in batch mode (Figure 4). The quantities of $16 \mathrm{~S}$ rRNA genes decayed by $90 \%$ during the 20 -day batch 

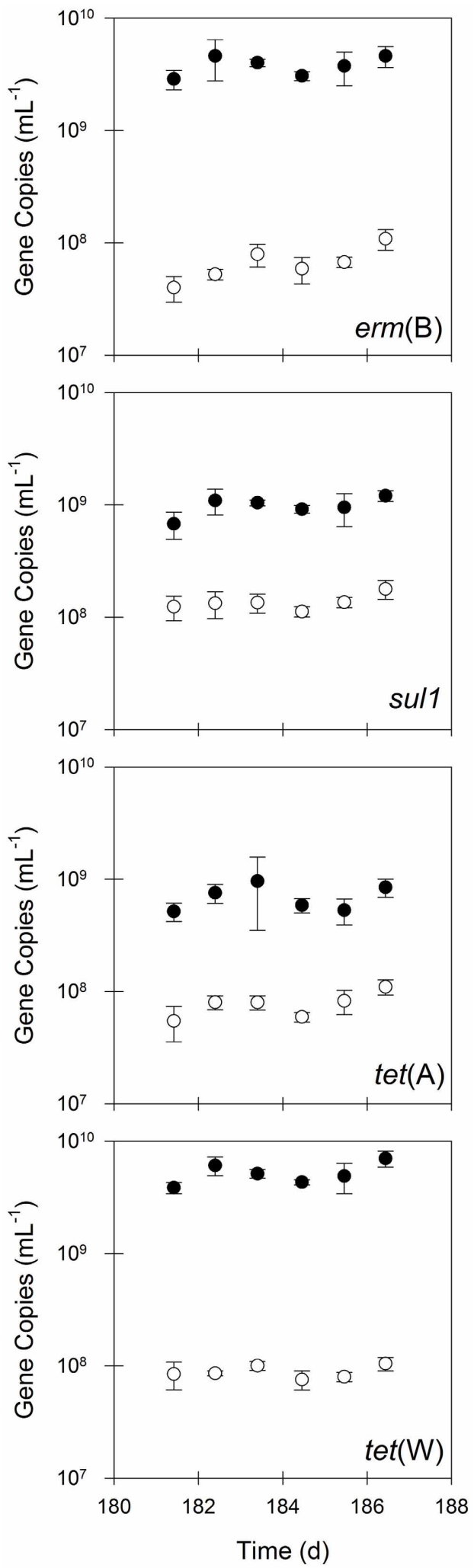

FIGURE 2 | The quantities of $\operatorname{erm}(\mathrm{B}), \operatorname{sul1}, \operatorname{tet}(\mathrm{A})$, and $\operatorname{tet}(\mathrm{W})$ in untreated (closed circles) and treated (open circles) residual solids. Values are the arithmetic mean of triplicate samples; error bars represent one standard deviation.
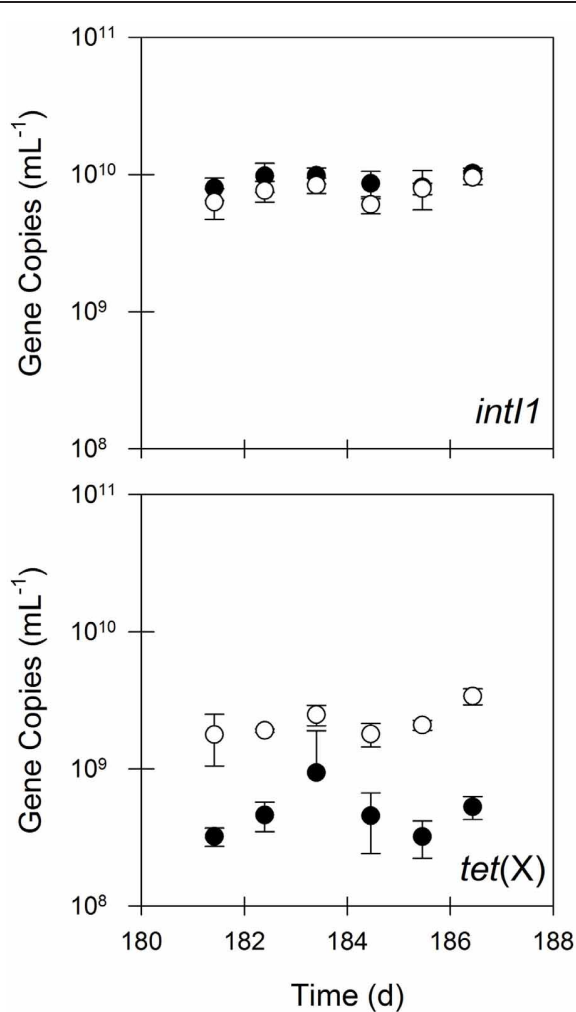

FIGURE 3 | The quantities of intl1 and tet(X) in untreated (closed circles) and treated (open circles) residual solids. Values are the arithmetic mean of triplicate samples; error bars represent one standard deviation.

experiment $\left(t_{1 / 2}=5.5 \mathrm{~d}\right.$; Table 3). In contrast, all Bacteroides spp. decayed by nearly four orders of magnitude over 20 days $\left(t_{1 / 2}=\right.$ $1.4 \mathrm{~d}$; Table 3), whereas human-specific Bacteroides spp. decayed to below the detection limit within one week of beginning the batch experimental phase $\left(t_{1 / 2}=4.6 \mathrm{~d}\right.$; Table 3$)$.

In contrast to operation in semi-continuous flow mode, the quantities of all of the antibiotic resistance determinants, including intI1 and tet $(\mathrm{X})$, declined in the batch experimental phase (Figure 5). The quantities of $\operatorname{erm}(\mathrm{B})$ and $\operatorname{tet}(\mathrm{W})$ declined by approximately two orders of magnitude during the 20-day experiment, whereas the quantities of intIl, sull, tet (A), and tet $(\mathrm{X})$ each declined by one order of magnitude during the same time period. Correspondingly, the first-order decay rates varied considerably among individual gene targets. The intII and tet $(\mathrm{X})$ genes decayed the most slowly, each with a half-life of approximately 6 days (Table 3 ). These rates of decay were statistically similar to each other as well as to the rate of decay for the $16 \mathrm{~S}$ rRNA gene (Table 4). In contrast, the first-order decay rates were significantly $(P<0.05)$ more rapid for the remaining gene targets, with half-lives ranging from 2.8 to 4.6 days (Table 3 ). These rates of decay were significantly faster than the decay rate for $16 \mathrm{~S}$ rRNA genes (Table 4).

\section{DISCUSSION}

The long-term goal of our research is to determine how the numerous technologies used to treat municipal wastewater can 

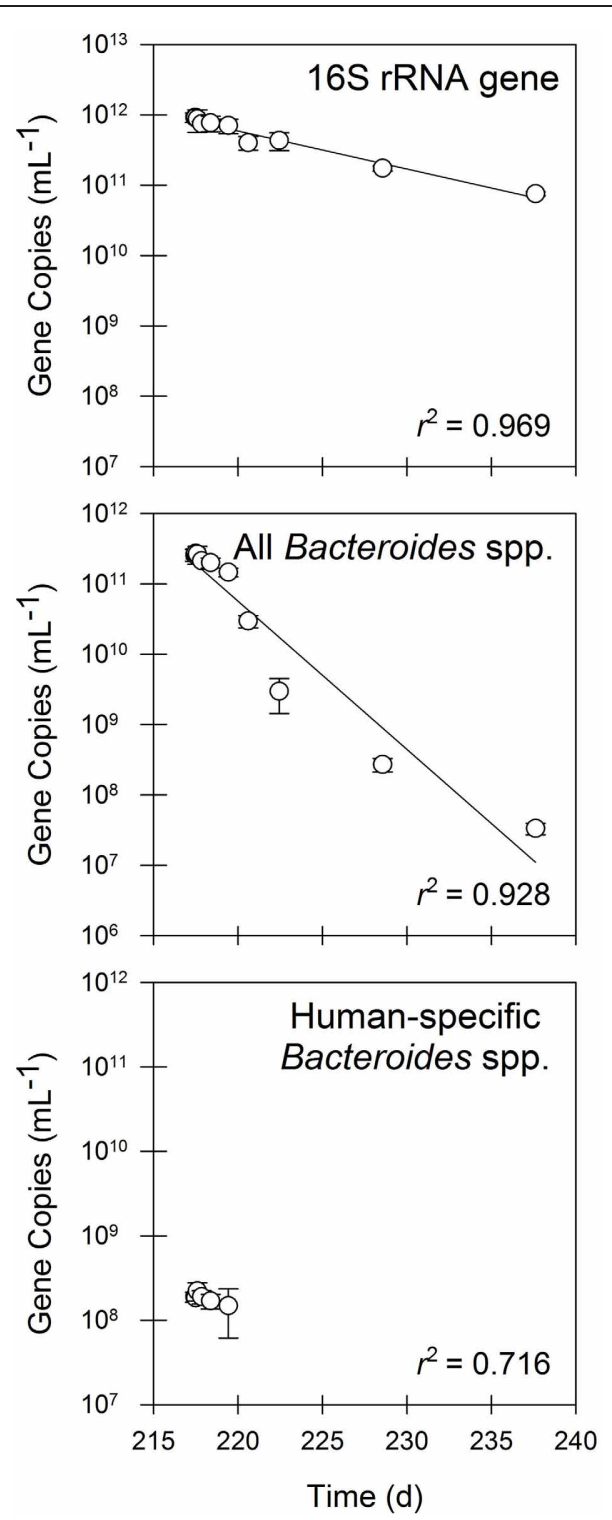

FIGURE 4 | The quantities of 16S rRNA genes, fecal indicator bacteria as measured by $16 \mathrm{~S}$ rRNA genes of all Bacteroides spp., and fecal indicator bacteria as measured by $16 \mathrm{~S}$ rRNA genes of human-specific Bacteroides spp. in residual solids undergoing batch treatment. Values are the arithmetic mean of triplicate samples; error bars represent one standard deviation.

simultaneously be used to eliminate the substantial quantities of $\mathrm{ARB}$ and ARGs that are known to exist in untreated sewage. The present study makes an important advance in our knowledge by elucidating the extent and rate by which aerobic digestion can be used to eliminate ARGs. This research is practically important because the overwhelming majority of ARB and ARGs in raw sewage ultimately end up in the residual wastewater solids, and a recent study suggested that more than 2200 municipal wastewater treatment facilities use this technology to produce more than 85,000 dry tons of treated wastewater solids in the United States each year (Beecher et al., 2007).
Table 3 | Summary of first-order degradation kinetic model parameter estimates for the 16S rRNA gene, fecal indicator bacteria as measured by $16 \mathrm{~S}$ rRNA genes of all Bacteroides spp., fecal indicator bacteria as measured by $16 \mathrm{~S}$ rRNA genes of human-specific Bacteroides spp., erm(B), intl1, sul1, tet(A), tet (W), and tet(X) during batch mode operation.

\begin{tabular}{lll}
\hline Gene target & $\begin{array}{l}\boldsymbol{k}\left(\mathbf{d a y}^{\mathbf{- 1}}\right) \pm \text { standard } \\
\text { error }\left(\mathbf{d a y}^{\mathbf{- 1}}\right)\end{array}$ & $\boldsymbol{t}_{\mathbf{1 / 2}}$ (days) \\
\hline 16S rRNA gene & $0.13 \pm 0.008$ & 5.5 \\
Bacteroides spp. & $0.49 \pm 0.048$ & 1.4 \\
Human-specific & $0.15 \pm 0.047$ & 4.6 \\
Bacteroides spp. & & \\
erm(B) & $0.19 \pm 0.025$ & 3.6 \\
int/1 & $0.11 \pm 0.011$ & 6.3 \\
sul1 & $0.15 \pm 0.009$ & 4.6 \\
tet(A) & $0.16 \pm 0.011$ & 4.4 \\
tet $(\mathrm{W})$ & $0.25 \pm 0.025$ & 2.8 \\
tet $(\mathrm{X})$ & $0.12 \pm 0.006$ & 5.7 \\
\hline
\end{tabular}

All rates were regressed from 10 data points (except human-specific Bacteroides spp., $n=6)$ and are statistically significant $(P<0.05)$.

In most cases, the rate of disappearance of different ARGs exceeded that of the total number of bacteria (as measured by 16S rRNA gene copies), suggesting that these ARGs were actively eliminated during the aerobic digestion process. Although there is only very limited data presently available in the published literature, these disappearance rates are generally similar to the rates that were previously observed during anaerobic digestion at $37^{\circ} \mathrm{C}$ (Diehl and LaPara, 2010). In contrast, the quantities of tet(X) and intI1 decayed at a rate similar to that of all bacteria, suggesting that these genes were passively eliminated, paralleling the decline in the total number of bacteria. This observation is substantially different than our previous study, in which both tet $(\mathrm{X})$ and intI1 rapidly declined in bench-scale anaerobic digestion processes operated at temperatures of $37^{\circ} \mathrm{C}$ or higher (Diehl and LaPara, 2010). Therefore, the rates by which different ARGs decay in a conventional aerobic digestion process are either similar to or slower than the decay rates observed in anaerobic digestion processes. This apparent inferiority of aerobic digestion is pertinent because anaerobic digestion is also a commonly used technology to treat residual wastewater solids (Tchobanoglous et al., 2003).

This research also demonstrated that reactor design has a major effect on the fate of ARGs during the treatment of residual municipal wastewater solids. The most obvious difference occurred with tet $(\mathrm{X})$, which declined under batch experimental conditions but increased substantially in semicontinuous flow conditions. Similarly, the quantity of intI declined under batch conditions but remained static during semicontinuous flow operation. In contrast, model results suggest that the quantities of erm(B) and tet (W) declined more rapidly in semi-continuous flow operation than would be suggested by the first-order decay coefficient elucidated under batch conditions (analyses not shown). Previous researchers have suggested that reactor design affects the removal of ARGs during wastewater solids digestion (Ma et al., 2011); our results support this 

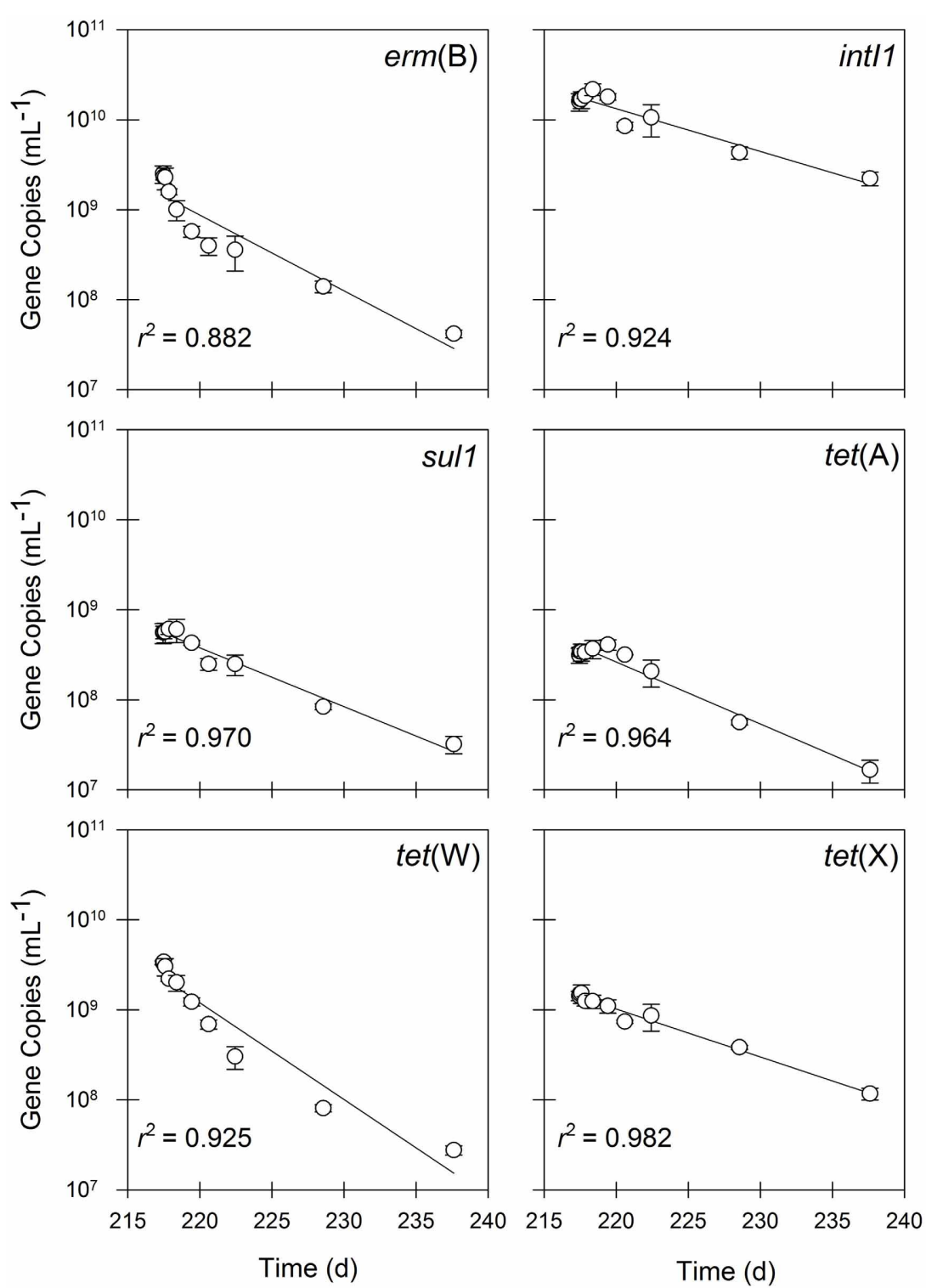

FIGURE 5 | The quantities of $\operatorname{erm}(\mathrm{B})$, intl1, sul1, $\boldsymbol{t e t}(\mathrm{A}), \boldsymbol{t e t}(\mathrm{W})$, and $\boldsymbol{t e t}(\mathrm{X})$ in residual solids undergoing batch treatment. Values are the arithmetic mean of triplicate samples; error bars represent one standard deviation.

hypothesis. Additional research is needed to clarify the importance of reactor design and the disappearance of ARGs during the digestion of wastewater solids.

A growing body of evidence suggests that class 1 integrons, which are linked to multiple antibiotic resistance, are particularly prominent in wastewater (Ghosh et al., 2009; Zhang et al., 2009b; Ramsden et al., 2010; Ma et al., 2011; Stalder et al., 2012). Our research has shown significant variation in removal efficiencies of intI1 depending on the specific technology (i.e., anaerobic digestion achieves better and more efficient removal than aerobic digestion) and the specific operating conditions (temperature, flow regime, etc.). Additional research is needed to better understand the fate and gene cassette content of class 1 integrons in residual solids treatment systems.
Prior research has suggested that sul1 flanks all class 1 integrons (Mazel, 2006). When the aerobic digester was operated in semi-continuous flow mode, however, the quantities of sul1 genes declined by almost an order of magnitude, whereas the quantities of intI1 were similar in the treated and in the untreated residual solids. Similarly, the rate by which sull declined in batch operating mode was significantly faster than the rate by which intI1 declined ( $P=0.01$; Table 4). This suggests that the coupling of the sull gene to class 1 integrons is not universal; additional research is needed to better understand the relationship between class 1 integrons and sul1 genes in the unit operations used to treat wastewater solids.

The most significant limitation of our research is the use of real-time quantitative PCR targeting various ARGs as a surrogate 
Table 4 | Values of $\boldsymbol{P}$ for comparing the relative statistical significance of different kinetic coefficients determined using Welch's $\boldsymbol{t}$-test for unequal $n$ and unequal sample variance.

\begin{tabular}{|c|c|c|c|c|c|c|c|c|c|}
\hline Gene & 16S rRNA gene & Bacteroides spp. & $\begin{array}{l}\text { Human-specific } \\
\text { Bacteroides spp. }\end{array}$ & $e r m(B)$ & intl1 & sul1 & $\operatorname{tet}(\mathrm{A})$ & $\operatorname{tet}(\mathrm{W})$ & $\operatorname{tet}(\mathrm{X})$ \\
\hline 16S rRNA gene & 1 & $3 \times 10^{-5}$ & 0.6 & 0.02 & 0.3 & 0.06 & 0.03 & $7 \times 10^{-4}$ & 0.8 \\
\hline Bacteroides spp. & & 1 & $2 \times 10^{-4}$ & $1 \times 10^{-4}$ & $2 \times 10^{-5}$ & $5 \times 10^{-5}$ & $6 \times 10^{-5}$ & $6 \times 10^{-4}$ & $3 \times 10^{-5}$ \\
\hline Human-specific & & & 1 & 0.4 & 0.4 & 1 & 0.9 & 0.1 & 0.6 \\
\hline \multicolumn{10}{|l|}{ Bacteroides spp. } \\
\hline $\operatorname{erm}(\mathrm{B})$ & & & & 1 & $9 \times 10^{-3}$ & 0.1 & 0.2 & 0.1 & 0.02 \\
\hline intl1 & & & & & 1 & 0.01 & $5 \times 10^{-3}$ & $2 \times 10^{-4}$ & 0.3 \\
\hline sul1 & & & & & & 1 & 0.6 & $4 \times 10^{-3}$ & 0.02 \\
\hline $\operatorname{tet}(\mathrm{A})$ & & & & & & & 1 & $6 \times 10^{-3}$ & 0.01 \\
\hline tet(W) & & & & & & & & 1 & $6 \times 10^{-4}$ \\
\hline $\operatorname{tet}(\mathrm{X})$ & & & & & & & & & 1 \\
\hline
\end{tabular}

for ARB. The genes quantified here could be present in dead but intact bacteria or in bacteria in which the gene is non-functional. Similarly, the identity of the ARB harboring the ARGs detected in this study, and their clinical significance, remain unknown. Finally, only a select group of ARGs were targeted; even though these genes represent several important classes of antibiotics and all three known molecular mechanisms of resistance to tetracyline, they cover a relatively small cross-section of possible resistance gene targets.

In conclusion, aerobic digestion can be used to eliminate ARGs in untreated wastewater solids, but rates can vary substantially depending on the reactor design and the specific ARG examined. This information represents a critical step

\section{REFERENCES}

Aminov, R. I., Garrigues-Jeanjean, N., and Mackie, R. I. (2001). Molecular ecology of tetracycline resistance: development and validation of primers for detection of tetracycline resistance genes encoding ribosomal protection. Appl. Environ. Microbiol. 67, 22-32.

Arnold, S., Gassner, B., Giger, T., and Zwahlen, R. (2004). Banning antimicrobial growth promoters in feedstuffs does not result in increased therapeutic use of antibiotics in medicated feed in pig farming. Pharmacoepidemiol. Drug Saf. 13, 323-331.

Auerbach, E. A., Seyfried, E. E., and McMahon, K. D. (2007). Tetracycline resistance genes in activated sludge wastewater treatment plants. Water Res. 41, 1143-1151.

Beecher, N., Crawford, K., Goldstein, N., Kester, G., Lono-Batura, M., Dziezyk, E., et al. (2007). Final Report: A National Biosolids Regulation, Quality, End Use and Disposal Survey. Tamworth, NH:
North East Biosolids and Residuals Association.

Bernhard, A. E., and Field, K. G. (2000). A PCR assay to discriminate human and ruminant feces on the basis of host differences in Bacteroides-Prevotella genes encoding 16S rRNA. Appl. Environ. Microbiol. 66, 4571-4574.

Bönemann, G., Stiens, M., Pühler, A., and Schlüter, A. (2006). Mobilizable IncQ-related plasmid carrying a new quinolone resistance gene, qnrS2, isolated from the bacterial community of a wastewater treatment plant. Antimicrob. Agents Chemother. 50, 3075-3080.

Chen, J., Yu, Z., Michel, F. C., Wittum, T., and Morrison, M. (2007). Development and application of real-time PCR assays for quantification of erm genes conferring resistance to macrolideslincosamides-streptogramin B in livestock manure and manure management systems. Appl. Environ. Microbiol. 73, 4407-4416.

toward our long-term goal of applying wastewater treatment technologies to mitigate the spread of antibiotic resistance. This knowledge is particularly useful to wastewater treatment engineers as they compare the relative merits of alternative residual solids treatment technologies and for designing specific unit operations to eliminate ARGs. Specifically, aerobic digestion technology, which is used by numerous full-scale municipal wastewater treatment facilities, appears less effective at eliminating ARGs than both conventional and high temperature anaerobic digestion.

\section{ACKNOWLEDGMENTS}

This work was supported, in part, by grant 0967176 from the National Science Foundation.

Clesceri, L. S., Greenberg, A. E., and Eaton, A. D. (eds.). (1999). Standard Methods for the Examination of Water and Wastewater, 20th Edn. Washington, DC: American Public Health Association.

da Silva, M. F., Tiago, I., Veríssimo, A., Boaventura, R. A. R., Nunes, O. C., and Manaia, C. M. (2006). Antibiotic resistance of enterococci and related bacteria in an urban wastewater treatment plant. FEMS Microbiol. Ecol. 55, 322-329.

Diehl, D. L., and LaPara, T. M. (2010). Effect of temperature on the fate of genes encoding tetracycline resistance and the integrase of Class 1 integrons within anaerobic and aerobic digesters treating municipal wastewater solids. Environ. Sci. Technol. 44, 9128-9133.

Edgar, R., Friedman, N., MolshanskiMor, S., and Qimron, U. (2012). Reversing bacterial resistance to antibiotics by phage-mediated delivery of dominant sensitive genes. Appl. Environ. Microbiol. 78, 744-751.
Galvin, S., Boyle, F., Hickey, P., Vellinga, A., Morris, D., and Cormican, M. (2010). Enumeration and characterization of antimicrobialresistant Escherichia coli bacteria in effluent from municipal, hospital, and secondary treatment facility sources. Appl. Environ. Microbiol. 76, 4772-4779.

Ghosh, S., Ramsden, S. J., and LaPara, T. M. (2009). The role of anaerobic digestion in controlling the release of tetracycline resistance genes and class 1 integrons from municipal wastewater treatment plants. Appl. Microbiol. Biotechnol. 84, 791-796.

Goldstein, C., Lee, M. D., Sanchez, S., Hudson, C., Phillips, B., Register, B., et al. (2001). Incidence of Class 1 and 2 integrases in clinical and commensal bacteria from livestock, companion animals, and exotics. Antimicrob. Agents Chemother. 45, 723-726.

Graham, D. W., Olivares-Rieumont, S., Knapp, C. W., Lima, L., Werner, D., and Bowen, E. (2011). Antibiotic 
resistance gene abundances associated with waste discharges to the Almendares River near Havana, Cuba. Environ. Sci. Technol. 45, 418-424.

Heuer, H., and Smalla, K. (2007). Manure and sulfadiazine synergistically increased bacterial antibiotic resistance in soil over at least two months. Environ. Microbiol. 9, 657-666.

Jabes, D. (2011). The antibiotic RandD pipeline: an update. Curr. Opin. Microbiol. 14, 564-569.

Kohanski, M. A., Dwyer, D. J., and Collins, J. J. (2010). How antibiotics kill bacteria: from targets to networks. Nat. Rev. Microbiol. 8, 423-435.

LaPara, T. M., Burch, T. R., McNamara, P. J., Tan, D. T., Yan, M., and Eichmiller, J. J. (2011). Tertiarytreated municipal wastewater is a significant point source of antibiotic resistance genes into Duluth-Superior Harbor. Environ. Sci. Technol. 45, 9543-9549.

Layton, A., McKay, L., Williams, D., Garrett, V., Gentry, R., and Sayler, G. (2006). Development of Bacteroides 16S rRNA gene TaqMan-based realtime PCR assays for estimation of total, human, and bovine fecal pollution in water. Appl. Environ. Microbiol. 72, 4214-4224.

Levy, S. B. (2005). Antibiotic resistance-the problem intensifies. Adv. Drug Deliv. Rev. 57, 1446-1450.

Levy, S. B., and Marshall, B. (2004). Antibacterial resistance worldwide: causes, challenges and responses. Nat. Med. 10, 122-129.

Levy, S. B., McMurry, L. M., Barbosa, T. M., Burdett, V., Courvalin, P., Hillen, W., et al. (1999). Nomenclature for new tetracycline resistance determinants. Antimicrob. Agents Chemother. 43, 1523-1524.

Ma, Y., Wilson, C. A., Novak, J. T., Riffat, R., Aynur, S., Murthy, S., et al. (2011). Effect of various sludge digestion conditions on sulfonamide, macrolide, and tetracycline resistance genes and class I integrons. Environ. Sci. Technol. 45, 7855-7861.

Mazel, D. (2006). Integrons: agents of bacterial evolution. Nat. Rev. Microbiol. 4, 608-620.

Munir, M., Wong, K., and Xagoraraki, I. (2011). Release of antibiotic resistant bacteria and genes in the effluent and biosolids of five wastewater utilities in Michigan. Water Res. 45, 681-693.

Muyzer, G., de Waal, E. C., and Uitterlinden, A. G. (1993). Profiling of complex microbial populations by denaturing gradient gel electrophoresis analysis of polymerase chain reaction-amplified genes coding for $16 \mathrm{~S}$ rRNA. Appl. Environ. Microbiol. 59, 695-700.

Ng, L.-K., Martin, I., Alfa, M., and Mulvey, M. (2001). Multiplex PCR for the detection of tetracycline resistant genes. Mol. Cell. Probes 15, 209-215.

Palumbi, S. R. (2001). Humans as the world's greatest evolutionary force. Science 293, 1786-1790.

Pruden, A., Pei, R., Storteboom, H., and Carlson, K. H. (2006). Antibiotic resistance genes as emerging contaminants: studies in northern Colorado. Environ. Sci. Technol. 40, 7445-7450.

Ramsden, S. J., Ghosh, S., Bohl, L. J., and LaPara, T. M. (2010). Phenotypic and genotypic analysis of bacteria isolated from three municipal wastewater treatment plants on tetracycline-amended and ciprofloxacin-amended growth media. J. Appl. Microbiol. 109, 1609-1618.

Roberts, M. C., Sutcliffe, J., Courvalin, P., Jensen, L. B., Rood, J., and Seppala, H. (1999). Nomenclature for macrolide and macrolidelincosamide-streptogramin B resistance determinants. Antimicrob. Agents Chemother. 43, 2823-2830.

Sambrook, J., Fritsch, E. F., and Maniatis, T. (1989). Molecular Cloning: A Laboratory Manual. 2nd Edn. Coldspring Harbor, NY: Coldspring Harbor Laboratory.
Schlüter, A., Szczepanowski, R., Pühler, A., and Top, E. M. (2007). Genomics of IncP-1 antibiotic resistance plasmids isolated from wastewater treatment plants provides evidence for a widely accessible drug resistance gene pool. FEMS Microbiol. Rev. 31, 449-477.

Seurinck, S., Defoirdt, T., Verstraete, W., and Siciliano, S. D. (2005). Detection and quantification of the human-specific HF183 Bacteroides $16 \mathrm{~S}$ rRNA genetic marker with real-time PCR for assessment of human faecal pollution in freshwater. Environ. Microbiol. 7, 249-259.

Spellberg, B., Blaser, M., Guidos, R. J., Boucher, H. W., Bradley, J. S., Eisenstein, B. I., et al. (2011). Combating antimicrobial resistance: policy recommendations to save lives. Clin. Infect. Dis. 52(Suppl. 5), S397-S428.

Stalder, T., Barraud, O., Casellas, M., Dagot, C., and Ploy, M.-C. (2012). Integron involvement in environmental spread of antibiotic resistance. Front. Microbiol. 3:119. doi: 10.3389/fmicb.2012.00119

Szczepanowski, R., Linke, B., Krahn, I., Gartemann, K.-H., Gützkow, T., Eichler, W., et al. (2009). Detection of 140 clinically relevant antibiotic-resistance genes in the plasmid metagenome of wastewater treatment plant bacteria showing reduced susceptibility to selected antibiotics. Microbiology 155, 2306-2319.

Tchobanoglous, G., Burton, F. L., and Stensel, H. D. (2003). Wastewater Engineering: Treatment and Reuse. 4th Edn. Boston, MA: McGraw-Hill.

Uyaguari, M. I., Fichot, E. B., Scott, G. I., and Norman, R. S. (2011). Characterization and quantitation of a novel \{beta\}-lactamase gene within a wastewater treatment facility and surrounding coastal ecosystem. Appl. Environ. Microbiol. 77, 8226-8233.

Wierup, M. (2001). The Swedish experience of the 1986 year ban of antimicrobial growth promoters, with special reference to animal health, disease prevention, productivity, and usage of antimicrobials. Microb. Drug Resist. 7, 183-190.

Zhang, T., Zhang, M., Zhang, X., and Fang, H. H. (2009a). Tetracycline resistance genes and tetracycline resistant Enterobacteriaceae in activated sludge of sewage treatment plants. Environ. Sci. Technol. 43, 3455-3460.

Zhang, X.-X., Zhang, T., Zhang, M., Fang, H. H. P., and Cheng, S.-P. (2009b). Characterization and quantification of class 1 integrons and associated gene cassettes in sewage treatment plants. Appl. Microbiol. Biotechnol. 82, 1169-1177.

Zhang, X.-X., and Zhang, T. (2011). Occurrence, abundance, and diversity of tetracycline resistance genes in 15 sewage treatment plants across China and other global locations. Environ. Sci. Technol. 45, 2598-2604.

Conflict of Interest Statement: The authors declare that the research was conducted in the absence of any commercial or financial relationships that could be construed as a potential conflict of interest.

Received: 21 November 2012; paper pending published: 17 December 2012; accepted: 24 January 2013; published online: 12 February 2013.

Citation: Burch TR, Sadowsky MJ and LaPara TM (2013) Aerobic digestion reduces the quantity of antibiotic resistance genes in residual municipal wastewater solids. Front. Microbio. 4:17. doi: 10.3389/fmicb.2013.00017

This article was submitted to Frontiers in Antimicrobials, Resistance and Chemotherapy, a specialty of Frontiers in Microbiology.

Copyright (C) 2013 Burch, Sadowsky and LaPara. This is an open-access article distributed under the terms of the Creative Commons Attribution License, which permits use, distribution and reproduction in other forums, provided the original authors and source are credited and subject to any copyright notices concerning any third-party graphics etc. 